\title{
Effects of small, Fijian community-based marine protected areas on exploited reef fishes
}

\author{
Cody Clements ${ }^{1,2}$, Victor Bonito ${ }^{3, *}$, Rikki Grober-Dunsmore ${ }^{4,5}$, Milika Sobey ${ }^{6}$ \\ ${ }^{1}$ School of Marine Studies, ${ }^{4}$ Institute of Applied Science, and ${ }^{6}$ School of Biological, Chemical, \\ \& Environmental Sciences, University of the South Pacific, Laucala Campus, Suva, Fiji \\ ${ }^{2}$ School of Biology, Georgia Institute of Technology, Atlanta, Georgia 30332, USA \\ ${ }^{3}$ Reef Explorer Fiji Ltd., Votua Village, Box 183, Korolevu, Fiji \\ ${ }^{5}$ National Oceanic and Atmospheric Administration (NOAA), Monterey Bay National Marine Sanctuary, 299 Foam Street, \\ Monterey, California 93940, USA
}

\begin{abstract}
No-take marine protected areas (MPAs) are commonly applied in community-based management schemes to sustain and enhance coral-reef fisheries. However, many MPAs in Fiji and the South Pacific are relatively small $\left(\leq 1 \mathrm{~km}^{2}\right)$, and few data exist regarding the effects of these MPAs on populations of exploited species. We used hook-and-line fishing surveys to assess whether 4 relatively small $\left(<1 \mathrm{~km}^{2}\right)$ community-based MPAs in Fiji (3 current, 1 former) were providing any commonly sought benefits to exploited reef-fish stocks. All of the MPAs had maintained no-take status for over $4 \mathrm{yr}$, although the former MPA was opened to fishing 4 mo before this study. The current MPAs exhibited significantly greater catch and biomass per unit effort, individual fish biomass, and/or percentage of reproductive-size fish than paired, adjacent fished areas, while this was not the case with the former MPA. Sites with intact MPAs also exhibited greater catch diversity than the former MPA site. Additionally, tag and recapture data from the 17 recaptured of 2650 tagged fish suggest site fidelity of these fishes, although fishes initially captured in the MPA at all 4 sites were later caught in fished areas, indicating that there is movement of fishes from the MPAs to fished areas. While the combination of these findings supports the utility of even relatively small MPAs as effective tools for the conservation of certain target species, it also suggests that MPA benefits may be quickly depleted and that even closures of extended duration may be insufficient for long-term fisheries management if the MPAs are not maintained.
\end{abstract}

KEY WORDS: Resource management - Coral reefs - Locally managed marine areas · Tag-recapture $\cdot$ Conservation $\cdot$ Fiji

\section{INTRODUCTION}

The overexploitation of coral-reef fisheries threatens the food security and livelihoods of coastal peoples (Jackson et al. 2001). This is especially problematic in developing countries, such as the island nations of the South Pacific, where it is estimated that $80 \%$ of the fisheries catch is for subsistence purposes, and limited resources are available for management (Dalzell et al. 1996). The ability of these fisheries to support future nutritional and economic demands is uncertain, as population and socio-economic growth continue to negatively impact these fisheries (Kronen et al. 2010). Because coral-reef fisheries are expected to remain the primary source of subsistence protein in most Pacific Island countries for the foreseeable future (Dalzell \& Adams 1994), there has been increasing recognition of the need to develop effective approaches to protecting, maintaining, and restoring these critical marine resources (Lubchenco et al. 2003).

No-take marine protected areas (MPAs) have gained considerable attention as an effective ecosys- 
tem-based tool for coral-reef fisheries management (Roberts \& Hawkins 2000, Lester \& Halpern 2008, Francini-Filho \& Moura 2008, Lester et al. 2009). An abundance of case studies from around the world demonstrate how species abundance, biomass, size, species richness, reproductive potential, and community structure have benefited from protection (Halpern \& Warner 2002, Gell \& Roberts 2003, Halpern \& Warner 2003, Claudet et al. 2008, Lester et al. 2009). Such findings contribute to the increasing number of MPAs being established in community-based management regimes throughout island nations of the South Pacific, in an attempt to enhance these critical fisheries and promote their sustainability (Govan 2009). Arguably no island nation has shown more progress toward establishment of these types of closures than Fiji, where there are more than 217 locally managed marine areas covering over $10800 \mathrm{~km}^{2}$ of 116 traditional Fijian fishing grounds, with nearly $600 \mathrm{~km}^{2}$ of the managed area included in no-take MPAs (Govan 2009). Many communities with MPAs follow the traditional tabu concept, in which an area is closed to fishing for some duration of time and then opened and harvested (Govan 2009). In contrast, few communities establish permanent no-take MPAs (Govan 2009) aimed to obtain benefits from the protection of reproductive stock and potential spillover of larvae and/or adult fish from the MPA to the fished area. While studies of other community-based management regimes in the region suggest that closures which allow periodic openings of limited duration may be equally, if not more, suitable for maintaining or enhancing stocks than permanently closed MPAs, the applicability and extent of these measures is cautioned (McClanahan et al. 2006, Bartlett et al. 2009) and remains controversial (Williams et al. 2006). Indeed, some question the traditional tabu system's ability to prevent depletion and inevitable recruitment failure of subsistence and commercial fisheries in Melanesia due to the temporary nature of most reserves (Foale \& Manele 2004).

Although locally managed MPA initiatives in Fiji are being embraced by many communities and received coordinated support from a national network of non-governmental and government organizations, most of the established MPAs are relatively small (median size of $1 \mathrm{~km}^{2}$, mean $2.6 \mathrm{~km}^{2}$ ), and few data have been collected regarding their efficacy (Govan 2009). Moreover, in Fiji, like many other Pacific island countries, socio-economic factors (e.g. enforcement potential, access to fishing grounds) often take precedence over ecological factors (e.g. size, habitat inclusion) when communities select lo- cations for MPAs (Aalbersberg et al. 2005). Because MPA effects may exhibit substantial time lags (Babcock et al. 2010) and be spatially idiosyncratic (Guidetti \& Sala 2007) and diverse in direction and magnitude (Halpern \& Warner 2002, Claudet et al. 2008), depending on the MPA location, size, habitat quality, closure duration, and species under consideration (Jennings 2000, Claudet et al. 2008, Lester et al. 2009, Claudet et al. 2010), the spatial and temporal aspects of Fijian MPAs undoubtedly impact their performance. Given the widespread application of these relatively small MPAs in Fiji and other South Pacific communities, it is important to determine what, if any, benefits these MPAs might offer to exploited reef fish populations.

We examined if any commonly sought benefits for exploited fish stocks are provided by 4 relatively small $\left(<1 \mathrm{~km}^{2}\right)$, community-based MPAs on Fiji's Coral Coast that have been established for over 4 yr. The principal reason that the communities established these MPAs was to protect exploited stocks of target species to sustain and enhance local fisheries (Tawake et al. 2002, Waqairagata 2010), a goal many community members perceive to have been successfully achieved (V. Bonito unpubl. data). One of the 4 MPAs examined had been opened to fishing 4 mo before the start of our study after more than $4 \mathrm{yr}$ of closure and was sampled to determine if any differences could be found between this former MPA and the adjacent unprotected fished area. Specifically, we assessed whether the MPAs exhibited greater catch per unit effort (as a proxy for fish abundance), fish biomass per unit effort, and/or percentage of potentially reproductive fish in the sampled population than paired, adjacent fished areas. Additionally, we examined the potential for movement of fish from the MPAs to the fished areas based on fish tagging and recapture.

\section{MATERIALS AND METHODS}

Research was carried out in the 2 traditional Fijian fishing grounds of the Komave and Korolevu-i-wai districts, which cover 4.89 and $9 \mathrm{~km}^{2}$ of coral reef habitat respectively. The study area is situated along the southwestern coast of Viti Levu, Fiji, which is known as the Coral Coast. The Coral Coast is characterized by fringing reefs with shallow intertidal platforms up to $700 \mathrm{~m}$ wide that are separated by a series of deep-water channels located at the discharge points of rivers. The reefs are composed of coral, rubble, sand, and algal flats interspersed with moats and tidal channels. 
Hook and line fishing was used to sample 4 sites, 2 in the traditional fishing ground of Korolevu-i-wai and 2 in Komave. These districts exhibit some of the most densely populated rural coastal areas in Fiji (Fong 2006), with populations ranging from 200 to 300 people in each traditional village and a total population of 7787 (Fiji Islands Bureau of Statistics 2007). Many residents of the districts practice a mixed income/subsistence lifestyle due to the burgeoning tourism industry (Fong 2006). At each site, sampling was conducted in the relatively small community-based MPA (Namada $\sim 0.5 \mathrm{~km}^{2}$, Votua $\sim 0.8 \mathrm{~km}^{2}$, Komave $\sim 0.5 \mathrm{~km}^{2}$, Namatakula $\sim 0.8 \mathrm{~km}^{2}$ ) as well as in the paired adjacent unprotected fished areas utilized by each respective community (Fig. 1). The MPAs in Namatakula, Votua, and Namada had been closed to fishing for over 4, 5 , and $6 \mathrm{yr}$ respectively at the time sampling commenced. The fished areas were geographically adjacent to the sampled MPAs, though sampling took place at least $200 \mathrm{~m}$ outside the boundaries of the MPAs, while sampling within the MPAs occurred at least $200 \mathrm{~m}$ inside the boundaries. The fourth MPA (in Komave) was opened to fishing 4 mo prior to the commencement of sampling after over 4 yr of closure. MPA study sites were selected to represent areas that were in close proximity to one another, encompassed similar habitat, and had minimal amounts of poaching observed.

Sampling was conducted during 48 fishing expeditions over an 8 mo period from March through May and August through December 2009. Sampling effort at each MPA and paired fished area was between 61 and 266 person-hours (total hours spent fishing by all fisher persons) (Table 1), with effort focused in the MPAs to allow a large number of fish to be tagged

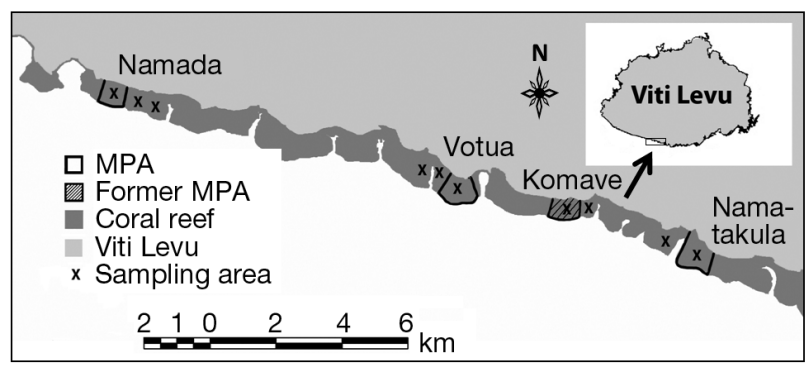

Fig. 1. Location of the 4 study sites and sampling locations at each site on Viti Levu, Fiji. Sampling was conducted within $150 \mathrm{~m}$ of the marked areas. MPA: no-take marine protected area within the MPA boundaries for the tag-and-recapture component of this study. Data recorded during each fishing expedition include the species and fork length $(\mathrm{cm})$ of each fish caught, along with the total number of fishers and time spent fishing each day. Most fish were also tagged with color-coated, numbered T-bar tags (Floy Tag \& Manufacturing) and released (Table 1). Any additional information, such as fish death due to deep hooking (i.e. the hook lodged in either the throat or gut) was also recorded. During the 8 mo period when sampling occurred and for 6 mo following the completion of sampling, community members reported the date and location of capture for any tagged fish that was recaptured.

Local fisher women from the village adjacent to each MPA conducted the sampling because they commonly hook-and-line fish and had detailed knowledge of their respective fishing grounds. The women fished at various locations both within the MPAs and adjacent fished areas using common baits, such as hermit crabs, octopus, and occasionally canned mackerel. The sampling locations were selected by the local women because the locations are, or were, traditionally fished locations. Attempts were made to restrict fishing to days (calm and generally sunny) and tides (approximately 1 to $3 \mathrm{~h}$ before or after low tide) when the women considered the weather was optimal for fishing at a given location.

Summary statistics of the catch composition were calculated for the MPA and fished area at each site. Family-level catch data were used to calculate the Shannon-Wiener diversity index for the MPA and fished area at each site. Because sample size was unequal among locations, a linear regression was conducted to determine if diversity was correlated with sample size. A similarity matrix of the ShannonWiener diversity based on normalized Euclidean distance was created and used in a multi-dimensional 
scaling (MDS) ordination plot to elucidate trends in similarity in catch diversity.

Catch per unit effort (CPUE) was calculated for each of the 48 fishing excursions using the formula CPUE $=\mathrm{n} / f$, where $\mathrm{n}$ is the number of fish caught on an excursion, and $f$ is the total person-hours spent fishing on a given day. Biomass per unit effort (BPUE) was determined for each of the 48 fishing excursions by first obtaining the weight $(W)$ of each fish using the equation $W=a L^{b}$, where $L$ is the recorded length, $a$ is the intercept, and $b$ is the slope of the fitted relationship. Length-weight relationships and subsequent $W$ values were obtained from FishBase (Froese \& Pauly 2010) for 41 of the 55 species caught in this study, which amounted to $78.2 \%$ of the species caught or $98.5 \%$ of the total individual fish caught (Appendix I). In cases where multiple $a$ and $b$ metrics for a given species were found, priority was given to those studies with the greatest number of fish (n) analyzed and those conducted in the geographical locale closest to Fiji. For those species where no length-weight metrics were available using fork length, $a$ and $b$ length-length metrics were used to convert the fork length of individuals to the appropriate length type. This involved substituting the relevant values into 1 of 2 equations: $T L=a+b F L$ or $S L=$ $(F L-a) / b$, where $F L$ is the fork length, $T L$ is the total length, $S L$ is the standard length, $a$ is the intercept, and $b$ is the slope of the fitted linear relationship. The BPUE for each fishing excursion was then calculated using the formula BPUE $=\sum W / f$.

CPUE and BPUE data for the total catch at each MPA and paired fished area were checked for normality using a Shapiro-Wilk test $(p=0.05)$. Due to non-normal data, Wilcoxon rank-sum pair-wise comparisons were used to detect differences in CPUE and BPUE between the MPA and paired fished area at each site. Wilcoxon rank-sum pair-wise comparisons of the mean biomass of individual epinephelids (the most abundant fish caught) were also conducted to detect differences between the MPA and fished areas at each site.

FishBase and the scientific literature were referenced to determine the maturity size $\left(L_{\mathrm{m}}\right)$ of as many species as possible. The length at which $50 \%$ of the population is estimated to be mature, $L_{50}$, was used in most cases. However, $L_{50}$ was substituted for higher metrics (i.e. $L_{90}$ ) if available. In cases where more than $1 L_{\mathrm{m}}$ was identified, priority was given to studies with the greatest number of fish analyzed or the study conducted in the geographical locale closest to Fiji. Data regarding the size at sexual maturity were summarized for each site and sampling area, and the total from the 3 currently intact MPAs (Namada, Namatakula, and Votua) was compared to the 5 fished locations using a $t$-test (data were normally distributed) to determine whether there was a difference in the percentage of reproductive-size fish caught in MPAs versus the fished areas.

The approximate location where each fish was tagged was recorded during fishing surveys, and the location of recaptured fish was determined by having fishers identify the recapture location on a map. The linear distance between the recapture locations and their respective tagging locations was determined using the measuring-ruler function on Google Earth (www.google.com/earth).

\section{RESULTS}

The overall catch included 2650 fishes representing 55 species; most of the catch comprised of epinephelids $(67.9 \%)$ and lethrinids (14.2\%). Epinephelids comprised the greatest proportion of the catch at all sites ( 45.5 to $89.6 \%$ ), with lethrinids generally comprising the second-largest proportion of the catch (1.9 to $26.5 \%$ ) except in the fished areas of Namatakula and Votua, where more labrids were caught than lethrinids (Fig. 2). The Shannon-Wiener diversity based on family-level catch data ranged from 0.485 to 1.395, with the lowest diversity recorded from Komave's fished area and the former MPA, while the highest diversity was recorded from Namatakula's MPA and Namada's fished area (Fig. 2). Catch diver-

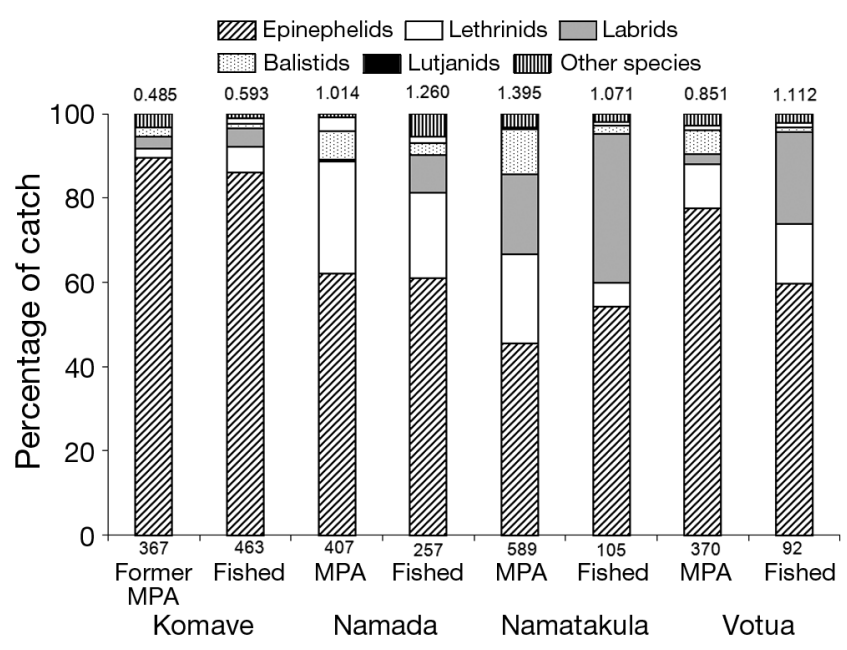

Fig. 2. Composition of catch by site and area. Numbers under the bars indicate the total number of fish caught while numbers over the bars indicate the Shannon-Wiener diversity index value of each catch based on family level analyses. MPA: no-take marine protected area 
sity was not correlated with sample size $\left(\mathrm{r}^{2}=0.0097\right.$, $\mathrm{p}=0.82)$. At all sites except Namatakula, the fished area had higher catch diversity than the MPA. An MDS ordination plot of the diversity at each sampling location illustrates that the Komave former MPA and fished area had similar diversity to each other (lowest catch diversity), while the fished areas in Votua and Namatakula and the Namada MPA (intermediate catch diversity) were also similar to each other (Fig. 3). Epinephelids comprised most of the catch at sites exhibiting low catch diversity.

Significant differences in CPUE between the MPA and fished area were observed at Votua $(z=-2.586$, $\mathrm{p}<0.01)$ and Namada $(z=-2.123, \mathrm{p}=0.03)$, with greater mean CPUE found in the MPAs (Fig. 4a). While the MPA at Namatakula also had a greater mean CPUE than the fished area, this difference was not significant $(z=-1.789, \mathrm{p}=0.07)$. In contrast, the fished area in Komave had a greater mean CPUE than the former MPA, though this difference was also not significant $(z=1.795, p=0.07)$.

Significant differences in BPUE between the MPA and fished areas were observed at all sites, with greater BPUE in the MPA at Namada $(z=-2.552, \mathrm{p}=$ $0.01)$, Namatakula $(z=-2.087, \mathrm{p}=0.04)$, and Votua $(z=-2.489, p=0.01)$ (Fig. 4b). However, at Komave, the BPUE was greater in the fished area than in the MPA $(z=1.984, p<0.05)$ (Fig. 4b). When compared to the Komave sites, the 3 maintained MPAs had mean BPUEs ranging from 1.7 to 3.2 times greater than Komave's fished area and 2.7 to 5.1 times greater than Komave's opened MPA.

Individual epinephelid mean biomass was significantly greater in all 3 MPAs and the former MPA than

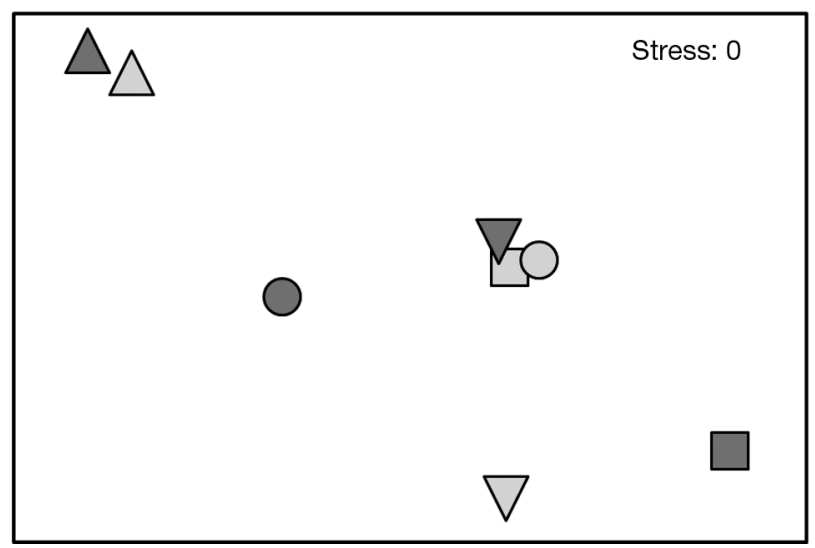

Fig. 3. Multi-dimensional scaling plot of the ShannonWiener diversity index value of each catch based on family level analyses from each location sampled. Sites are represented by shapes - Komave $(\Delta)$, Namada $(\nabla)$, Namatakula (口), Votua (O) - and areas by colors (dark gray = MPA; light gray $=$ fished area). MPA: no-take marine protected area
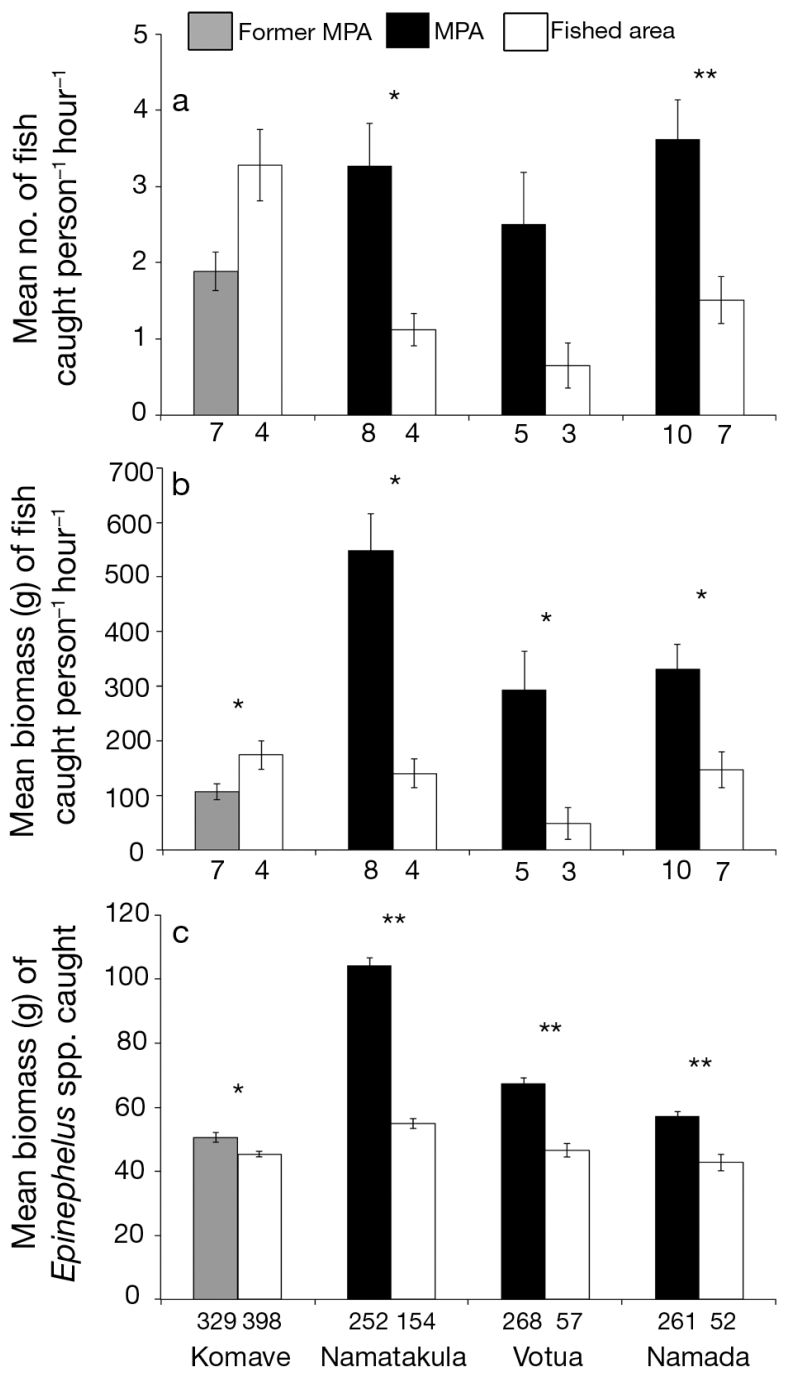

Fig. 4. Mean (a) CPUE, (b) BPUE, and (c) biomass of individual Epinephelus spp. \pm 1 SE. Asterisks indicate significant differences for pair-wise Wilcoxon rank-sum tests $\left({ }^{*} p<0.05\right.$, $\left.{ }^{* *} \mathrm{p}<0.01\right)$. Numbers below the bars indicate number of sampling days (a \& b) and number of fish sampled (c); CPUE: catch per unit effort; BPUE: biomass per unit effort. MPA: no-take marine protected area

in the adjacent fished areas of Namada $(z=-12.699$, $\mathrm{p}<0.0001)$, Namatakula $(z=-4.338, \mathrm{p}<0.0001)$, Votua $(z=-3.470, \mathrm{p}<0.001)$, and Komave $(z=-2.533$, $\mathrm{p}=0.01$ ) (Fig. 4c). Epinephelids had 89.8, 44.3, 33.1, and $11.3 \%$ greater individual mean biomass in the MPA than in the fished area at Namada, Namatakula, Votua, and Komave respectively.

A review of the literature yielded values of the size at sexual maturity (SSM) for 33 of the 55 species, or approximately $60.0 \%$ of all species caught. This translated to $97.5 \%$ of all individual fish caught in this study. The intact MPA catches consisted of 43.5 to $81.5 \%$ of fishes with sizes $\geq \mathrm{SSM}$, while the compa- 
rable fraction in the adjacent fished areas and former MPA ranged from 25.7 to $36.8 \%$ (Fig. 5). Differences in the percentage of fishes that were $\geq$ SSM between the MPA and fished areas ranged from $17.4 \%$ at Namatakula to as great as $45.9 \%$ at Namada (Fig. 5). Combined, the 3 intact MPAs in Namada, Namatakula, and Votua had double the percentage of fishes caught within their respective boundaries that were $\geq$ SSM (mean 61.2 $\pm 11.1 \mathrm{SE}$ ) compared to their adjacent fished areas and the former MPA and fished area in Komave (mean $30.8 \pm 2.3 \mathrm{SE}$ ), a difference that was significant $(t=3.5200, \mathrm{p}=0.01)$.

Of the 2379 fish tagged with external FLOY T-bar tags, 17 were recaptured by community fishers

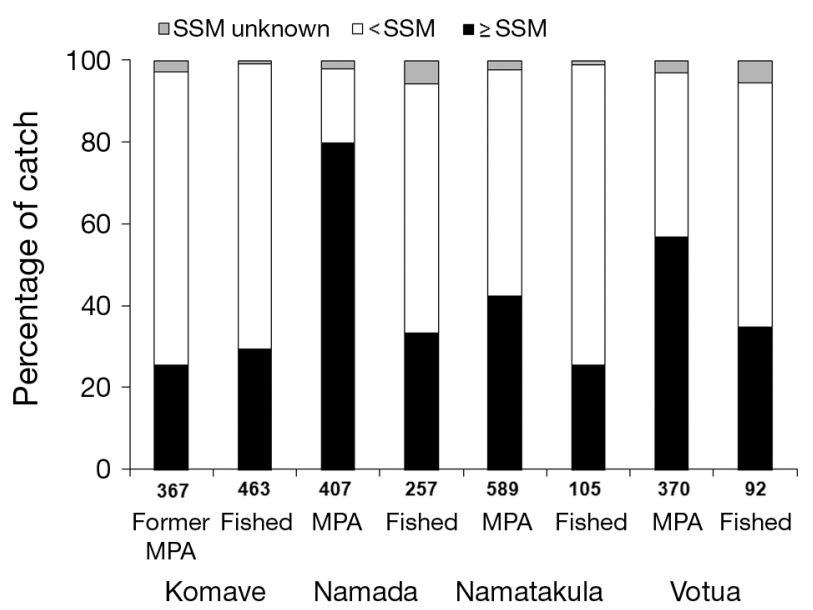

Fig. 5. Percentage of the fish caught that were greater than or equal to size at sexual maturity (SSM) by site and area. Numbers below the bars represent total number of fish caught. MPA: no-take marine protected area
(Table 2). Of the 17 recaptures, 5 were fish that were initially caught in an MPA or former MPA area that were later recaptured in a continuously fished area. All but 2 of the fishes recaptured were caught at the same site or a nearby fishing spot $<1 \mathrm{~km}$ away from their initial capture site. Only 1 fish, an Epinephelus merra, was recaptured at a completely different site approximately $8.5 \mathrm{~km}$ from the site of its initial capture.

\section{DISCUSSION}

Though relatively small, the 3 intact communitybased MPAs in Namada, Namatakula, and Votua appear to promote the recovery of exploited fish species, as indicated by greater CPUE, BPUE, epinephelid biomass, and percentage of reproductive-sized fishes found in these areas. These findings suggest that the MPAs harbor higher-density fish assemblages that consist of larger and more potentially reproductive individuals. Thus, these MPAs have the potential to contribute disproportionately more in terms of reproductive output per area than the fished areas and are likely important for sustaining local fisheries. Additionally, movement of fishes from the MPAs to the fished areas occurred at all sites, indicating that fishers do occasionally catch fish that benefit from MPA protection and habitat. However, it appears that any benefits to exploited species examined in this study obtained by the establishment of these MPAs may be quickly removed, as indicated by the results from the former MPA in Komave. In con-

Table 2. Tag-recapture information, including fish species, tagging location, recapture location, and approximate distance between tagging and recapture location $(\mathrm{km})$. MPA: no-take marine protected area

\begin{tabular}{|lllr|}
\hline Fish species & Tagging location & Recapture location & $\begin{array}{c}\text { Approximate distance } \\
\text { traveled (km) }\end{array}$ \\
\hline $\begin{array}{l}\text { Lethrinus harak } \\
\text { Epinephelus merra }\end{array}$ & Namada fished area & Namada fished area & $<0.2$ \\
Epinephelus hexagonatus & Namada fished area & Namada fished area & $<0.2$ \\
Epinephelus merra & Namada fished area & Namada fished area & $<0.2$ \\
Cheilinus trilobatus & Namada fished area & Namada fished area & 0.6 \\
Lethrinus harak & Namada fished area & Namada fished area & 0.6 \\
Epinephelus merra & Namada fished area & Namada fished area & 0.6 \\
Epinephelus merra & Namada MPA & Namada fished area & 1.5 \\
Lethrinus harak & Votua MPA & Namada fished area & 8.5 \\
Lethrinus harak & Komave fished area & Komave fished area & $<0.2$ \\
Sphyraena jello & Komave fished area & Komave fished area & $<0.2$ \\
Epinephelus merra & Komave former MPA & Komave fished area & 0.4 \\
Epinephelus merra & Komave former MPA & Komave fished area & 0.4 \\
Epinephelus merra & Komave fished area & Komave fished area & $<0.2$ \\
Epinephelus merra & Komave fished area & Komave fished area & $<0.2$ \\
Epinephelus hexagonatus & Komave fished area & Komave fished area & 0.3 \\
Epinephelus hexagonatus & Komave former MPA & Komave former MPA & 0.3 \\
& Namatakula MPA & Namatakula fished area & 0.6 \\
\hline
\end{tabular}


trast to other MPAs, the former MPA in Komave had lower CPUE and BPUE and did not harbor a greater proportion of reproductive-size fishes than the adjacent fished area. It did, however, still harbor epinephelids with significantly greater biomass, though the difference between the 2 areas was less pronounced than at the 3 sites that had maintained their MPAs.

Catch composition data from the 4 sites indicate that sites with maintained MPAs harbor more diverse assemblages of hook-and-line-catchable fish both inside and outside the MPAs, suggesting further benefits may result from maintaining the MPAs. Because only 1 former MPA was sampled, it is possible that the difference in catch diversity may be due to other factors, such as differences in habitat. However, our in situ observations along with benthic data pre- and post-MPA-establishment (Coral Cay Conservation 2005a,b, V. Bonito unpubl. data) indicate no major habitat differences between Komave and the other 3 sites sampled upon commencement of management efforts by the community. We attribute the morehomogenized catch composition at Komave compared to other sites to the lack of protection from fishing pressure, as observed in other studies (McClanahan et al. 2010). Shifts in multispecies community structure are expected following exploitation, with increases of small and/or early maturing species and decreases of large and/or slow maturing species (Jennings et al. 2001). The catch at Komave consisted almost entirely of epinephelid species (> $80 \%$ ), which exhibit a relatively high growth rate (Pothin et al. 2004) and have a size at sexual maturity amongst the lowest of any species commonly caught in our study. Due to these life-history characteristics, epinephelids are highly resistant to fishing pressure, with a minimum population doubling time of less than 15 mo for the most prevalent epinephelid caught, Epinephelus merra (Froese \& Pauly 2010). Additionally, while fishes susceptible to fishery-dependent methods (i.e. gear selectivity and fish behavior) have the potential to bias catch composition, fishes known to exhibit aggressive or competitively dominant behavior, such as certain species of balistids (McClanahan 2000), comprise a small proportion of the catch composition at all site areas, even less than that of known subordinate species of labrids (McClanahan 2000). Furthermore, catch composition may underestimate the degree of site separation and differences in fish communities due to limitations of fishery-dependent methods. Thus, even modest differences in catch composition may reflect larger ecological impacts (McClanahan et al. 2010).
As with all survey method biases, those inherent in CPUE have the potential to confound our results (Harley et al. 2001) and differ depending on species' characteristics (i.e. physical traits and behavior) (Haggarty \& King 2006). Several studies have highlighted the effect of fishing pressure on fish behavior, noting that the flight distance of some fish species (Kulbicki 1998) and/or families (Januchowski-Hartley et al. 2011) may increase with fishing pressure and that some fish exhibit shorter flight distances within protected areas than in neighboring fished areas (Feary et al. 2010). However, these biases are not consistent among habitats or species (Bohnsack \& Bannerot 1986) and may be influenced by the gear used or targetstatus of specific fish (Jennings \& Polunin 1995, Feary et al. 2010, Januchowski-Hartley et al. 2011). Januchowski-Hartley et al. (2011) found that serranids and lutjanids, which are primarily caught via hook and line rather than spear gun at our study sites, showed no significant changes in flight distance between different fishing pressures. For epinephelids, which comprised the majority of the catch at all our sites, any difference in flight response between the MPA and fished area is expected to be well within the effective range of hand-line methods, as is the case with the lesscommonly caught lutjanids (Januchowski-Hartley et al. 2011), and thus unlikely to have greatly influenced our results.

As in other studies that have used CPUE as a proxy for fish densities (Attwood 2000, Kaunda-Arara \& Rose 2004, Haggarty \& King 2006), we found that CPUE indicated that the intact MPAs in Votua and Namada harbored significantly greater densities of fish than the adjacent fished areas. Sampling at Namatakula also indicated greater densities of fish in the MPA, though this result was not statistically significant. With CPUE in the MPA more than 3-fold greater than in the fished area, this lack of significance is likely the result of low statistical power due to the low number of replicate days of fishing. Conversely, we recorded nearly double the CPUE in the fished area in Komave than in the former MPA. Because fishing pressure in Komave was directed towards the MPA when it was opened, the adjacent fished area was likely subjected to less fishing pressure, perhaps allowing catchable stocks an opportunity to recover, thus producing a greater (though not significantly so) CPUE from the fished area compared to the former MPA. While the CPUE in the fished area in Komave was comparable to the intact MPAs at other sites, BPUE data add perspective; 
although numerous, the fishes caught at Komave were relatively small.

The BPUE values observed for all our study sites are lower than those previously documented in Fiji. In Fiji's remote Lau island group, Kuster et al. (2006) documented a mean BPUE for hand-line fishing per fisher of $1.4 \pm 0.3 \mathrm{~kg} \mathrm{~h}^{-1}$, which is substantially lower than the mean per-fisher rate of $2.3 \mathrm{~kg} \mathrm{~h}^{-1}$ recorded a decade earlier by Dalzell et al. (1996). While differences in location and target species make drawing any conclusions regarding temporal declines inappropriate, the BPUE rates observed in our study suggest that fishing pressure is relatively high at our study sites and indicate that MPAs probably serve as important refuges for exploited species.

Increases in fish density and size in MPAs are expected to translate into increased reproductive potential, thus providing fisheries benefits through enhanced recruitment (Gell \& Roberts 2003, Palumbi 2004). Studies of various fish species have documented a relationship between increased size in spawning females and reproductive performance, including larger eggs (Hislop 1988, Marteinsdottir \& Steinarsson 1998), increased egg production (Bohnsack 1990), and faster-growing larvae that are more resistant to starvation (Berkeley et al. 2004). Additionally, female egg production can increase exponentially with body size (Bohnsack 1990, Evans et al. 2008). The intact MPA catches had percentages of fish equal to or greater than the size at sexual maturity that were 1.5 to 2.3-fold greater than in the adjacent fished areas. Considering that CPUE was also 2.4 to 3.9 -fold greater in the maintained MPAs, the potential benefits obtained from these MPAs through enhanced reproductive output is likely to be considerable and important for ensuring the sustainability of the fishery. Indeed, enhanced reproductive output from the MPAs is a possible explanation for the significant increases in the abundance of serranids, lethrinids, and lutjanids documented (using underwater visual censuses) between 2004 and 2007 across both MPA and fished areas of the Korolevu-i-wai fishing ground that includes our Namada and Votua sites (Simpson 2011). Similarly, lower levels of reproductive stock, such as those documented in Komave, could contribute to the significant decrease in targeted fish documented between 2004 and 2009 across 3 sites in the Komave fishing ground (including our Komave site) where MPAs were not maintained and/or rotated over the study period (Bonito et al. 2011).

Recaptures of tagged fishes, though few, indicate a great deal of site fidelity in the fishes caught during this study but also indicate that there is indeed move- ment of fish between the MPAs and fished areas. These results are consistent with acoustic tagging data obtained from Lethrinus spp. acoustically tracked in and around Votua's MPA (Grober-Dunsmore et al. 2009), which showed occasional movement of fishes into and out of the MPA and provide further evidence that fishers do have opportunities to catch fishes that benefit from the MPA. Furthermore, the Epinephelus merra recaptured more than $8 \mathrm{~km}$ down the coast from its initial capture site indicates that there is some longer-distance movement of the fish species that we tagged. This was especially surprising, given that E. merra is expected to exhibit high site fidelity (Heemstra \& Randall 1993). The low percentage of recaptured fishes from this study may be attributed to subsequent mortality of tagged fishes, low tag-retention rates, or a lack of reporting by fishers or may be indicative of large population sizes of catchable fishes. Because tagged fishes have been incidentally observed in maintained MPA sites over 20 mo after tagging began, we do not believe that high mortality due to tagging or low tag retention led to the low recapture rate but rather that the low recapture rate is likely reflective of the population size and general site fidelity of tagged fishes. A similar tagging study carried out in MPAs of Fiji's Kubulau district yielded comparable recapture results, with only 3 fishes, out of 549, recaptured during the 18 mo following tagging (Egli et al. 2010). Additionally, the active participation of community members and their interest in this study conducted in their fishing ground decreased the probability that recovered tags were not reported.

Modeling efforts suggest that while permanent reserves will offer the greatest benefits, rotational or periodic harvests in marine reserves may still produce positive benefits for the biomass and abundance of target species depending on their life history characteristics (Gerber et al. 2003, Lester \& Halpern 2008). This has been supported by empirical evidence from other community-based MPAs in the Pacific, such as in Papua New Guinea (McClanahan et al. 2006) and Vanuatu (Bartlett et al. 2009), and most often in areas with low populations, low market connectivity, and high social capital. However, MPA managers should consider the frequency, intensity, and scope of harvest events involved with periodic closures (Bartlett et al. 2009) in relation to MPA stakeholder objectives. Some MPA regimes involving short, infrequent harvests may be fairly benign in their effects on certain exploited stocks and, at the same time, capable of accomplishing community goals (i.e. stockpiling resources to be harvested for a particular event) (McClanahan et al. 2006, Bartlett et 
al. 2009). However, other studies, such as our own, found that former reserves that have been opened to fishing often experience an immediate post-harvest depletion of resources (Russ \& Alcala 1998, Ferraris et al. 2005) and may prove ineffective if fishes are harvested to a degree that prevents long-term improvement (Williams et al. 2006).

Our study demonstrates that measurable contributions to the recovery of exploited fish stocks can be obtained through even relatively small MPAs if they are maintained, and reiterates the effectiveness of community-based management initiatives for achieving common fisheries-management objectives (Cinner \& Aswani 2007). However, data from Komave, where an MPA maintained for over 4 yr was recently opened, indicate that even extended closures do not prevent rapid depletion of the protected area stock within a relatively short time period. Our study corroborates the findings of other studies, indicating that fishes can be removed with alarming efficiency (Foale \& Day 1997), and impermanent closures may result in slipping baselines (Foale \& Manele 2004, Knowlton \& Jackson 2008), even when the closures are for a considerable duration.

Acknowledgements. We thank B. Donaldson, A. Bogiva, and the villagers of the Korolevu-I-Wai and Komave districts in Fiji for their assistance with data collection. We also thank J. Comley for his constructive comments during various stages of this project, as well as M. Hay, D. Rasher, and anonymous reviewers for constructive comments on a previous draft of this manuscript. This research was supported by generous funding from the NOAA International Coral Reef Conservation Program (award NA08NOS4630338).

\section{LITERATURE CITED}

Aalbersberg B, Tawake A, Parras T (2005) Village by village: recovering Fiji's coastal fisheries. In: Mock G, Whitten $P$ (eds) The wealth of the poor: managing ecosystems to fight poverty. World Resources Institute, Washington, DC, p 144-152

Attwood C (2000) De Hoop Marine Protected Area, South Africa. In: Roberts CM, Hawkins JP (eds) Fully protected marine reserves: a guide. WWF Endangered Seas Campaign, Washington DC, USA, and Environment Department, University of York, p 104-105

Babcock RC, Shears NT, Alcala AC, Barrett NS and others (2010) Decadal trends in marine reserves reveal different rates of change in direct and indirect effects. Proc Natl Acad Sci USA 107:18256-18261

- Bartlett CY, Manua C, Cinner JM, Sutton S and others (2009) Comparisons of outcomes of permanently closed and periodically harvested coral reef reserves. Conserv Biol 23:1475-1484

Berkeley SA, Chapman C, Sogard SM (2004) Maternal age is a determinant of larval growth and survival in a marine fish, Sebastes melanops. Ecology (USA) 85:1258-1264
Bohnsack JA (subcommittee chair) (1990) The potential of marine fisheries reserves for reef fish management in the U.S. southern Atlantic. Snapper-Grouper Plan Development Team report to the South Atlantic Fishery Management council. NMFS-SEFC-261, NOAA Technical Memorandum, Silver Spring, MD

Bohnsack JA, Bannerot SP (1986) A stationary visual census technique for quantitatively assessing community structure of coral reef fishes. NMFS 41, NOAA Technical Report, Silver Spring, MD

Bonito V, Comley J, Simpson R, Waqairagata F (2011) Scaling up local to national management approaches: lessons learned from two co-managed Fijian fishing grounds. 2nd Fiji Islands Conservation Science Forum, Suva, Sep $14-16,2011$

> Cinner JE, Aswani S (2007) Integrating customary management into marine conservation. Biol Conserv 140:201-216

Claudet J, Osenberg CW, Benedetti-Cecchi L, Domenici P and others (2008) Marine reserves: size and age do matter. Ecol Lett 11:481-489

Claudet J, Osenberg CW, Domenici P, Badalamenti F and others (2010) Marine reserves: fish life history and ecological traits matter. Ecol Appl 20:830-839

Coral Cay Conservation (2005a) Fisheries resource assessment report for the Korolevu-i-wai iqoliqoli. Coral Cay Conservation, Suva

Coral Cay Conservation (2005b) Fisheries resource assessment report for the Komave iqoliqoli. Coral Cay Conservation, Suva

Dalzell P, Adams TJH (1994) The present status of coastal fisheries production in the South Pacific islands. Secretariat of the Pacific Community, Inshore Fisheries Research Programme 25th Regional Technical Meeting on Fisheries, Noumea, New Caledonia, March 14-18, 1994

Dalzell P, Adams TJH, Polunin NVC (1996) Coastal fisheries in the Pacific islands. Oceanogr Mar Biol Annu Rev 34: 395-531

Ebisawa A (2006) Reproductive and sexual characteristics in five Lethrinus species in waters off the Ryukyu Islands. Ichthyol Res 53:269-280

Egli DP, Moy W, Naisilisili W (2010) Fish movement in MPAs on coral reefs in Kubulau, Fiji. Technical Report no. 05/10, Wildlife Conservation Society-Fiji, Suva

Evans RD, Russ GR, Kritzer JP (2008) Batch fecundity of Lutjanus carponotatus and implications of no-take marine reserves on the Great Barrier Reef, Australia. Coral Reefs 27:179-189

Feary DA, Cinner JE, Graham NAJ, Januchowski-Hartley FA (2011) Effects of customary marine closures on fish behavior, spear-fishing Success, and underwater visual surveys. Conserv Biol 25:341-349

Ferraris J, Pelletier D, Kulbicki M, Chauvet C (2005) Assessing the impact of removing reserve status on the Abore Reef fish assemblage in New Caledonia. Mar Ecol Prog Ser 292:271-286

Fiji Islands Bureau of Statistics (2007) Provisional Results: 2007 household and population census: Nadroga. Unpublished raw data, available at www.statsfiji.gov.fj/

$>$ Foale SJ, Day RW (1997) Stock assessment of trochus (Trochus niloticus) fisheries at West Nggela, Solomon Islands, with notes on management. Fish Res 33:1-16

Foale S, Manele B (2004) Social and political barriers to the use of Marine Protected Areas for conservation and fisheries management in Melanesia. Asia Pac Viewp 45: 373-386

Fong PS (2006) Community-based coastal resources management in Fiji Islands: case study of Korolevu-i-wai Dis- 
trict, Nadroga. MS thesis, University of the South Pacific, Suva

Francini-Filho RB, Moura RL (2008) Evidence for spillover of reef fishes from a no-take marine reserve: an evaluation using the before-after control-impact (BACI) approach. Fish Res 93:346-356

Froese R, Pauly D (eds) (2010) FishBase. www.fishbase.org, version $(03 / 2010)$

Gell FR, Roberts CM (2003) Benefits beyond the boundaries: the fishery effect of marine reserves. Trends Ecol Evol 18:448-455

Gerber LR, Botsford LW, Hastings A, Possingham HP, Gaines SD, Palumbi SR, Andelman S (2003) Population models for marine reserve design: a retrospective and prospective synthesis. Ecol Appl 13:47-64

Govan H (2009) Status and potential of locally-managed Marine Areas in the South Pacific: meeting nature conservation and sustainable livelihood targets through wide-spread implementation of LMMAs. SPREP/WWF/ WorldFish-Reefbase/CRISP, Suva

Grober-Dunsmore R, Bonito V, Aalbersberg W, Bogiva A, Comley J (2009) Evaluation and enhancement of marine conservation efforts in Tikina Komave and Navosa Province: CPUE and fish tagging study. Inaugural Fiji Islands Conserv Sci Forum, Suva, Aug 5-7, 2009

Guidetti P, Sala E (2007) Community-wide effects of marine reserves in the Mediterranean. Mar Ecol Prog Ser 335: 43-56

Haggarty DR, King JR (2006) CPUE as an index of relative abundance for near shore fisheries. Fish Res 31:229-239

Halpern BS, Warner RR (2002) Marine reserves have rapid and lasting effects. Ecol Lett 5:361-366

Halpern BS, Warner RR (2003) Matching marine reserve design to research objectives. Proc Biol Sci 270: 1871-1878

> Harley CDG, Myers RA, Dunn A (2001) Is catch-per-uniteffort proportional to abundance? Can J Fish Aquat Sci 58:1760-1772

Heemstra PC, Randall JE (1993) Groupers of the world (family Serranidae, subfamily Epinephelinae): an annotated and illustrated catalogue of the grouper, rockcod, hind, coral grouper and lyretail species known to date. FAO Spec Cat 16:1-382

Hislop JRG (1988) The influence of maternal length and age on the size and weight of the eggs and the relative fecundity of the haddock, Melanogrammus aeglefinus, in British waters. J Fish Biol 32:923-930

Jackson JBC, Kirby MX, Berger WH, Bjorndal KA and 15 others (2001) Historical overfishing and the recent collapse of coastal ecosystems. Science 293:629-637

Januchowski-Hartley FA, Graham NAJ, Feary DA, Morove T, Cinner JE (2011) Fear of fishers: human predation explains behavioural changes in coral reef fishes. PLoS ONE 6:e22761

Jennings S (2000) Patterns and prediction of population recovery in marine reserves. Rev Fish Biol Fish 10: 209-231

> Jennings S, Polunin NVC (1995) Biased underwater visual census biomass estimates for target species in tropical reef fisheries. J Fish Biol 47:733-736

Jennings S, Kaiser MJ, Reynolds JD (2001) Marine fisheries ecology. Blackwell Publishing, Malden, MA

Kaunda-Arara B, Rose GA (2004) Effects of marine reef National Parks on fishery CPUE in coastal Kenya. Biol Conserv 118:1-13

Knowlton N, Jackson J (2008) Shifting baselines, local impacts, and global change on coral reefs. PLoS Biol 6:e54
Kronen M, Magron F, McArdle B, Vunisea A (2010) Reef finfishing pressure risk model for Pacific island countries and territories. Fish Res 101:1-10

Kulbicki M (1998) How the acquired behavior of commercial reef fishes may influence the results obtained from visual censuses. J Exp Mar Biol Ecol 222:11-30

Kuster C, Vuki V, Zann L (2006) Validation of the accuracy of household reporting of subsistence fishing catch and effort: a Fijian case study. Fish Manage Ecol 13:177-184

Lester SE, Halpern BS (2008) Biological responses in marine no-take reserves versus partially protected areas. Mar Ecol Prog Ser 367:49-56

Lester SE, Halpern BS, Grorud-Colvert K, Lubchenco J and others (2009) Biological effects within no-take marine reserve: a global synthesis. Mar Ecol Prog Ser 384:33-46

> Lubchenco J, Palumbi SR, Gaines SD, Andelman S (2003) Plugging a hole in the ocean: the emerging science of marine reserves. Ecol Appl 13:3-7

Marteinsdottir G, Steinarsson A (1998) Maternal influence on the size and viability of Iceland cod Gadus morhua eggs and larvae. J Fish Biol 52:1241-1258

May D, Robinson G (2005) Kaledupa fisheries pilot project 2005: An assessment of the fisheries of Kaledupa. Operation Wallacea Trust Indonesia

> McClanahan TR (2000) Recovery of the coral reef keystone predator, Balistapus undulatus, in East African marine parks. Biol Conserv 94:191-198

McClanahan TR, Marnane MJ, Cinner JE, Kiene WE (2006) A comparison of marine protected areas and alternative approaches to coral-reef management. Curr Biol 16: 1408-1413

> McClanahan TR, Kaunda-Arara B, Omukoto JO (2010) Composition and diversity of fish and fish catches in closures and open-access fisheries of Kenya. Fish Manag Ecol 17:63-76

Palumbi SR (2004) Why mothers matter. Nature 430:621-622

Pothin K, Letourneur Y, Lecomte-Finiger R (2004) Age, growth and mortality of the tropical grouper Epinephelus merra (Pisces: Serranidae) on Reunion Island, SW Indian Ocean. Vie Milieu Life \& Environment 54:193-202

Roberts CM, Hawkins JP (2000) Fully-protected marine reserves: a guide. WWF Endangered Seas Campaign, Washington DC, USA, and Environment Department, University of York

Russ GR, Alcala AC (1998) Natural fishing experiments in marine reserves 1983-1993: roles of life history and fishing intensity in family responses. Coral Reefs 17: 399-416

Sadovy Y (1999) Marketing and monitoring live reef fishes in Hong Kong, an update. SPC Live Reef Fish Trade Inf Bull 4:47-51

Simpson R (2011) Assessing MPA effectiveness using finfish indicators - a case study from the Korolevu-i-wai qoliqoli. 2nd Fiji Islands Conserv Sci Forum, Suva, Sep 14-16, 2011

Tawake A, Meo S, Fong S (2002) Summary report on the Tikina Korolevu-i-wai community resource management workshop. University of the South Pacific Institute of Applied Science, Suva

Waqairagata F (2010) Summary report on the review of the 2004 management plan for Tikina Komave, Navosa Province 2009/2010. University of the South Pacific Institute of Applied Science, Suva

Williams ID, Walsh WJ, Miyasaka A, Friedlander AM (2006) Effects of rotational closure on coral reef fishes in Waikiki-Diamond Head Fishery Management Area, Oahu, Hawaii. Mar Ecol Prog Ser 310:139-149 
Appendix 1. Table A1. Biological measures of maturity, length, and weight data used for all species caught during the study. Lm: length at maturity; Lm metric: percentage at sexual maturity; L type: type of length measurement; FL: fork length; TL: total length; SL: standard length; $a$ : the $y$-intercept; $b$ : the slope of the fitted linear relationship; n/a: not available or unknown. All data are from FishBase except those with superscripts

\begin{tabular}{|c|c|c|c|c|c|c|c|c|c|}
\hline \multirow{2}{*}{ Species } & \multirow[t]{2}{*}{$\mathrm{Lm}$} & \multirow{2}{*}{$\begin{array}{c}\mathrm{Lm} \\
\text { metric }\end{array}$} & \multirow{2}{*}{ L type } & \multicolumn{2}{|c|}{ Length-Length } & \multirow{2}{*}{$\begin{array}{c}\text { Converted } \\
\text { Lm }\end{array}$} & \multicolumn{2}{|c|}{ Length-Weight } & \multirow[t]{2}{*}{ L type } \\
\hline & & & & $a$ & $b$ & & $a$ & $b$ & \\
\hline Abudefduf sexfasciatus & $\mathrm{n} / \mathrm{a}$ & $\mathrm{n} / \mathrm{a}$ & $\mathrm{n} / \mathrm{a}$ & $\mathrm{n} / \mathrm{a}$ & $\mathrm{n} / \mathrm{a}$ & $\mathrm{n} / \mathrm{a}$ & 0.0213 & 3.152 & FL \\
\hline Balistapus undulatus & $13.8^{\mathrm{b}}$ & L50 & $\mathrm{n} / \mathrm{a}$ & $0.000^{\mathrm{a}}$ & $1.000^{\mathrm{a}}$ & $\mathrm{n} / \mathrm{a}$ & 0.0058 & 3.554 & TL \\
\hline Caranx melampygus & $35^{\mathrm{a}}$ & L50 & SL & $0.150^{\mathrm{a}}$ & $1.076^{\mathrm{a}}$ & 37.810 & 0.0235 & 2.920 & FL \\
\hline Caranx papuensis & $\mathrm{n} / \mathrm{a}$ & $\mathrm{n} / \mathrm{a}$ & $\mathrm{n} / \mathrm{a}$ & $\mathrm{n} / \mathrm{a}$ & $\mathrm{n} / \mathrm{a}$ & $\mathrm{n} / \mathrm{a}$ & 0.0249 & 2.910 & FL \\
\hline Cephalopholis argus & $\mathrm{n} / \mathrm{a}$ & $\mathrm{n} / \mathrm{a}$ & $\mathrm{n} / \mathrm{a}$ & $\mathrm{n} / \mathrm{a}$ & $\mathrm{n} / \mathrm{a}$ & $\mathrm{n} / \mathrm{a}$ & 0.0093 & 3.181 & FL \\
\hline Cephalopholis urodeta & $\mathrm{n} / \mathrm{a}$ & $\mathrm{n} / \mathrm{a}$ & $\mathrm{n} / \mathrm{a}$ & $\mathrm{n} / \mathrm{a}$ & $\mathrm{n} / \mathrm{a}$ & $\mathrm{n} / \mathrm{a}$ & $\mathrm{n} / \mathrm{a}$ & $\mathrm{n} / \mathrm{a}$ & $\mathrm{n} / \mathrm{a}$ \\
\hline Cheilinus chlorourus & $19.8^{\mathrm{b}}$ & L50 & $\mathrm{n} / \mathrm{a}$ & $\mathrm{n} / \mathrm{a}$ & $\mathrm{n} / \mathrm{a}$ & $\mathrm{n} / \mathrm{a}$ & $\mathrm{n} / \mathrm{a}$ & $\mathrm{n} / \mathrm{a}$ & $\mathrm{n} / \mathrm{a}$ \\
\hline Cheilio inermis & $21.7^{\mathrm{b}}$ & L50 & $\mathrm{n} / \mathrm{a}$ & $\mathrm{n} / \mathrm{a}$ & $\mathrm{n} / \mathrm{a}$ & $\mathrm{n} / \mathrm{a}$ & 0.0035 & 3.082 & FL \\
\hline Cheilinus trilobatus & $19.8^{\mathrm{b}}$ & L50 & $\mathrm{n} / \mathrm{a}$ & $\mathrm{n} / \mathrm{a}$ & $\mathrm{n} / \mathrm{a}$ & $\mathrm{n} / \mathrm{a}$ & $\mathrm{n} / \mathrm{a}$ & $\mathrm{n} / \mathrm{a}$ & $\mathrm{n} / \mathrm{a}$ \\
\hline Coris gaimard & $\mathrm{n} / \mathrm{a}$ & $\mathrm{n} / \mathrm{a}$ & $\mathrm{n} / \mathrm{a}$ & $\mathrm{n} / \mathrm{a}$ & $\mathrm{n} / \mathrm{a}$ & $\mathrm{n} / \mathrm{a}$ & $\mathrm{n} / \mathrm{a}$ & $\mathrm{n} / \mathrm{a}$ & $\mathrm{n} / \mathrm{a}$ \\
\hline Dascyllus trimaculatus & $\mathrm{n} / \mathrm{a}$ & $\mathrm{n} / \mathrm{a}$ & $\mathrm{n} / \mathrm{a}$ & $\mathrm{n} / \mathrm{a}$ & $\mathrm{n} / \mathrm{a}$ & $\mathrm{n} / \mathrm{a}$ & 0.0313 & 3.043 & FL \\
\hline Epinephelus bleekeri & $30^{\mathrm{d}}$ & $\mathrm{n} / \mathrm{a}$ & & $0.000^{\mathrm{a}}$ & $1.000^{\mathrm{a}}$ & & 0.0183 & 2.891 & $\mathrm{TL}$ \\
\hline Epinephelus hexagonatus & $19^{\mathrm{a}}$ & L50 & $\mathrm{TL}$ & $0.000^{\mathrm{a}}$ & $1.000^{\mathrm{a}}$ & 19.000 & 0.0177 & 2.930 & $\mathrm{TL}$ \\
\hline Epinephelus lanceolatus & $105^{\mathrm{b}}$ & L50 & $\mathrm{n} / \mathrm{a}$ & $0.000^{\mathrm{a}}$ & $1.000^{\mathrm{a}}$ & & 0.0173 & 3.000 & $\mathrm{TL}$ \\
\hline Epinephelus merra & $14.2^{\mathrm{b}}$ & L50 & FL & $\mathrm{n} / \mathrm{a}$ & n/a & $\mathrm{n} / \mathrm{a}$ & 0.0158 & 2.966 & FL \\
\hline Epinephelus spilotoceps & 24 & $\mathrm{n} / \mathrm{a}$ & $\mathrm{n} / \mathrm{a}$ & $\mathrm{n} / \mathrm{a}$ & $\mathrm{n} / \mathrm{a}$ & $\mathrm{n} / \mathrm{a}$ & 0.0041 & 3.346 & FL \\
\hline Epinephelus tauvina & $61.1^{\mathrm{a}}$ & L50 & TL & $0.000^{\mathrm{a}}$ & $1.015^{\mathrm{a}}$ & 60.197 & 0.0156 & 2.930 & $\mathrm{TL}$ \\
\hline Halichoeres hortulanus & $12.8^{\mathrm{a}}$ & L50 & TL & $0.000^{\mathrm{a}}$ & $1.000^{\mathrm{a}}$ & 12.800 & 0.0119 & 3.064 & $\mathrm{TL}$ \\
\hline Halichoeres trimaculatus & $12.6^{\mathrm{b}}$ & L50 & $\mathrm{n} / \mathrm{a}$ & $\mathrm{n} / \mathrm{a}$ & $\mathrm{n} / \mathrm{a}$ & $\mathrm{n} / \mathrm{a}$ & 0.0275 & 2.736 & \\
\hline Lethrinus amboiensis & $29.2^{\mathrm{b}}$ & L50 & $\mathrm{n} / \mathrm{a}$ & $\mathrm{n} / \mathrm{a}$ & $\mathrm{n} / \mathrm{a}$ & $\mathrm{n} / \mathrm{a}$ & 0.0201 & 2.964 & $\mathrm{n} / \mathrm{a}$ \\
\hline Lethrinus harak & $21.1^{\mathrm{c}}$ & L90 & FL & $\mathrm{n} / \mathrm{a}$ & $\mathrm{n} / \mathrm{a}$ & $\mathrm{n} / \mathrm{a}$ & 0.017 & 3.043 & FL \\
\hline Lethrinus lentjan & $20^{\mathrm{a}}$ & L50 & $\mathrm{n} / \mathrm{a}$ & $\mathrm{n} / \mathrm{a}$ & $\mathrm{n} / \mathrm{a}$ & $\mathrm{n} / \mathrm{a}$ & 0.0197 & 2.986 & FL \\
\hline Lethrinus obsoletus & $25.7^{\mathrm{c}}$ & L60 & FL & $\mathrm{n} / \mathrm{a}$ & $\mathrm{n} / \mathrm{a}$ & $\mathrm{n} / \mathrm{a}$ & 0.0173 & 3.026 & FL \\
\hline Lethrinus ornatus & $20^{\mathrm{c}}$ & L90 & FL & $\mathrm{n} / \mathrm{a}$ & $\mathrm{n} / \mathrm{a}$ & $\mathrm{n} / \mathrm{a}$ & 0.0201 & 2.964 & $\mathrm{n} / \mathrm{a}$ \\
\hline Lethrinus xanthochilus & $29.9^{\mathrm{b}}$ & L50 & $\mathrm{n} / \mathrm{a}$ & $\mathrm{n} / \mathrm{a}$ & $\mathrm{n} / \mathrm{a}$ & $\mathrm{n} / \mathrm{a}$ & 0.0201 & 2.964 & FL \\
\hline Lutjanus argentimaculatus & $51.9^{\mathrm{a}}$ & L50 & $\mathrm{TL}$ & $0.000^{\mathrm{a}}$ & $1.018^{\mathrm{a}}$ & 50.982 & 0.0336 & 2.792 & $\mathrm{TL}$ \\
\hline Lutjanus bohar & $26.8^{\mathrm{b}}$ & L50 & $\mathrm{n} / \mathrm{a}$ & $\mathrm{n} / \mathrm{a}$ & n/a & $\mathrm{n} / \mathrm{a}$ & 0.017 & 3.035 & FL \\
\hline Lutjanus ehrenbergii & $15.8^{\mathrm{b}}$ & L50 & $\mathrm{n} / \mathrm{a}$ & $0.000^{\mathrm{a}}$ & $1.032^{\mathrm{a}}$ & $\mathrm{n} / \mathrm{a}$ & 0.0026 & 3.335 & $\mathrm{TL}$ \\
\hline Lutjanus fulvus & $17.8^{\mathrm{b}}$ & L50 & $\mathrm{n} / \mathrm{a}$ & $\mathrm{n} / \mathrm{a}$ & $\mathrm{n} / \mathrm{a}$ & $\mathrm{n} / \mathrm{a}$ & 0.0243 & 2.928 & FL \\
\hline Lutjanus kasmira & $13.9^{\mathrm{b}}$ & L50 & $\mathrm{n} / \mathrm{a}$ & $\mathrm{n} / \mathrm{a}$ & $\mathrm{n} / \mathrm{a}$ & $\mathrm{n} / \mathrm{a}$ & 0.0117 & 3.136 & FL \\
\hline Lutjanus monostigma & $24.1^{\mathrm{b}}$ & L50 & $\mathrm{n} / \mathrm{a}$ & $\mathrm{n} / \mathrm{a}$ & $\mathrm{n} / \mathrm{a}$ & $\mathrm{n} / \mathrm{a}$ & 0.0222 & 2.913 & FL \\
\hline Lutjanus quinquelineatus & $17^{\mathrm{b}}$ & L50 & $\mathrm{n} / \mathrm{a}$ & $\mathrm{n} / \mathrm{a}$ & $\mathrm{n} / \mathrm{a}$ & $\mathrm{n} / \mathrm{a}$ & 0.0296 & 2.851 & FL \\
\hline Lutjanus semicinctus & $\mathrm{n} / \mathrm{a}$ & $\mathrm{n} / \mathrm{a}$ & $\mathrm{n} / \mathrm{a}$ & $\mathrm{n} / \mathrm{a}$ & $\mathrm{n} / \mathrm{a}$ & $\mathrm{n} / \mathrm{a}$ & 0.0224 & 3.002 & FL \\
\hline Mulloidichthys pflugeri & $\mathrm{n} / \mathrm{a}$ & $\mathrm{n} / \mathrm{a}$ & $\mathrm{n} / \mathrm{a}$ & $\mathrm{n} / \mathrm{a}$ & $\mathrm{n} / \mathrm{a}$ & $\mathrm{n} / \mathrm{a}$ & $\mathrm{n} / \mathrm{a}$ & $\mathrm{n} / \mathrm{a}$ & $\mathrm{n} / \mathrm{a}$ \\
\hline Monotaxis grandoculis & $25.5^{\mathrm{b}}$ & L50 & $\mathrm{n} / \mathrm{a}$ & $\mathrm{n} / \mathrm{a}$ & $\mathrm{n} / \mathrm{a}$ & $\mathrm{n} / \mathrm{a}$ & 0.023 & 3.022 & FL \\
\hline Novaculichthys taeniourus & $13.8^{\mathrm{b}}$ & L50 & $\mathrm{n} / \mathrm{a}$ & $\mathrm{n} / \mathrm{a}$ & $\mathrm{n} / \mathrm{a}$ & $\mathrm{n} / \mathrm{a}$ & $\mathrm{n} / \mathrm{a}$ & $\mathrm{n} / \mathrm{a}$ & $\mathrm{n} / \mathrm{a}$ \\
\hline Parapercis hexophthalma & $\mathrm{n} / \mathrm{a}$ & $\mathrm{n} / \mathrm{a}$ & $\mathrm{n} / \mathrm{a}$ & $\mathrm{n} / \mathrm{a}$ & $\mathrm{n} / \mathrm{a}$ & $\mathrm{n} / \mathrm{a}$ & 0.0068 & 3.157 & FL \\
\hline Parapercis millipunctata & $\mathrm{n} / \mathrm{a}$ & $\mathrm{n} / \mathrm{a}$ & $\mathrm{n} / \mathrm{a}$ & $\mathrm{n} / \mathrm{a}$ & $\mathrm{n} / \mathrm{a}$ & $\mathrm{n} / \mathrm{a}$ & $\mathrm{n} / \mathrm{a}$ & $\mathrm{n} / \mathrm{a}$ & $\mathrm{n} / \mathrm{a}$ \\
\hline Parupeneus indicus & $\mathrm{n} / \mathrm{a}$ & $\mathrm{n} / \mathrm{a}$ & $\mathrm{n} / \mathrm{a}$ & $\mathrm{n} / \mathrm{a}$ & $\mathrm{n} / \mathrm{a}$ & $\mathrm{n} / \mathrm{a}$ & 0.0142 & 3.114 & FL \\
\hline Parupeneus multifasciatus & $13.8^{\mathrm{b}}$ & L50 & $\mathrm{n} / \mathrm{a}$ & $\mathrm{n} / \mathrm{a}$ & $\mathrm{n} / \mathrm{a}$ & $\mathrm{n} / \mathrm{a}$ & 0.0114 & 3.211 & FL \\
\hline Parupeneus spilurus & $\mathrm{n} / \mathrm{a}$ & $\mathrm{n} / \mathrm{a}$ & $\mathrm{n} / \mathrm{a}$ & $\mathrm{n} / \mathrm{a}$ & $\mathrm{n} / \mathrm{a}$ & $\mathrm{n} / \mathrm{a}$ & 0.0192 & 3.022 & FL \\
\hline Rhinecanthus aculeatus & $14^{\mathrm{a}}$ & L50 & $\mathrm{TL}$ & $0.000^{\mathrm{a}}$ & $1.000^{\mathrm{a}}$ & 14.000 & 0.0522 & 2.641 & FL \\
\hline Scarus frenatus & $\mathrm{n} / \mathrm{a}$ & $\mathrm{n} / \mathrm{a}$ & $\mathrm{n} / \mathrm{a}$ & $\mathrm{n} / \mathrm{a}$ & $\mathrm{n} / \mathrm{a}$ & $\mathrm{n} / \mathrm{a}$ & $\mathrm{n} / \mathrm{a}$ & $\mathrm{n} / \mathrm{a}$ & $\mathrm{n} / \mathrm{a}$ \\
\hline Scarus spinus & $\mathrm{n} / \mathrm{a}$ & $\mathrm{n} / \mathrm{a}$ & $\mathrm{n} / \mathrm{a}$ & $0.000^{\mathrm{a}}$ & $0.920^{\mathrm{a}}$ & $\mathrm{n} / \mathrm{a}$ & 0.0279 & 3.06 & $\mathrm{SL}$ \\
\hline Siderea picta & $\mathrm{n} / \mathrm{a}$ & $\mathrm{n} / \mathrm{a}$ & $\mathrm{n} / \mathrm{a}$ & $\mathrm{n} / \mathrm{a}$ & $\mathrm{n} / \mathrm{a}$ & $\mathrm{n} / \mathrm{a}$ & $\mathrm{n} / \mathrm{a}$ & $\mathrm{n} / \mathrm{a}$ & $\mathrm{n} / \mathrm{a}$ \\
\hline Sphyraena jello & $55.4^{\mathrm{b}}$ & L50 & $\mathrm{n} / \mathrm{a}$ & $\mathrm{n} / \mathrm{a}$ & $\mathrm{n} / \mathrm{a}$ & $\mathrm{n} / \mathrm{a}$ & 0.014 & 2.81 & FL \\
\hline Synodus dermatogenys & $\mathrm{n} / \mathrm{a}$ & $\mathrm{n} / \mathrm{a}$ & $\mathrm{n} / \mathrm{a}$ & $\mathrm{n} / \mathrm{a}$ & $\mathrm{n} / \mathrm{a}$ & $\mathrm{n} / \mathrm{a}$ & 0.0046 & 3.346 & FL \\
\hline Terapon jarbua & $13^{\mathrm{a}}$ & L50 & $\mathrm{n} / \mathrm{a}$ & $\mathrm{n} / \mathrm{a}$ & $\mathrm{n} / \mathrm{a}$ & $\mathrm{n} / \mathrm{a}$ & 0.0154 & 3.082 & FL \\
\hline Thalassoma hardwicke & $8.5^{\mathrm{a}}$ & L50 & $\mathrm{n} / \mathrm{a}$ & $\mathrm{n} / \mathrm{a}$ & $\mathrm{n} / \mathrm{a}$ & $\mathrm{n} / \mathrm{a}$ & 0.0178 & 2.978 & FL \\
\hline Tylosurus crocodilus & $\mathrm{n} / \mathrm{a}$ & $\mathrm{n} / \mathrm{a}$ & $\mathrm{n} / \mathrm{a}$ & $\mathrm{n} / \mathrm{a}$ & $\mathrm{n} / \mathrm{a}$ & $\mathrm{n} / \mathrm{a}$ & 0.0008 & 3.205 & FL \\
\hline Zenarchopterus dispar & $\mathrm{n} / \mathrm{a}$ & $\mathrm{n} / \mathrm{a}$ & $\mathrm{n} / \mathrm{a}$ & $\mathrm{n} / \mathrm{a}$ & $\mathrm{n} / \mathrm{a}$ & $\mathrm{n} / \mathrm{a}$ & $\mathrm{n} / \mathrm{a}$ & n/a & $\mathrm{n} / \mathrm{a}$ \\
\hline
\end{tabular}

